\title{
Evaluation of the Hearing System in Chronic Obstructive Pulmonary Disease Patients
}

\author{
Kronik Obstrüktif Akciğer Hastalığı Hastalarındaki Işitme Sisteminin Değerlendirilmesi
}

\author{
(D) Oral Burak DEMIREL, (D) Tolga ERSÖZLÜ, (D) Mahmut DENIZ \\ Tekirdağ Namık Kemal University Faculty of Medicine, Department of Otorhinolaryngology, Head and Neck Surgery, Tekirdağ, Turkey
}

\begin{abstract}
Aim: This study aimed to examine the effect of chronic hypoxemia on auditory functions in chronic obstructive pulmonary disease (COPD) patients.

Materials and Methods: Sixty patients who had pulmonary function test (PFT) and diagnosed with COPD were included in the study. Four study groups and a control group were created in the study. Each study group was determined based on forced expiratory volume (FEV1) and FEV1/forced vital capacity (FVC) ratio. Groups consisted of mild, moderate, severe and very severe COPD patients. Each group included 15 patients. The control group consisted of 30 patients with an FEV1/FVC ratio of $>70 \%$. All patients underwent pure tone audiometry and otoacoustic emission (OAE) test. Results: According to the audiological evaluation, a statistically significant difference was found between the severe and very severe group and the control group $(\mathrm{p}<0.01)$.

Conclusion: The results of the present study showed that auditory mechanisms may also be affected in patients with severe and very severe COPD. The authors of this study argue that necessary measures should be taken in the early stages of the disease for COPD patients to prevent the negative effects of chronic hypoxemia on the auditory system.
\end{abstract}

Keywords: Chronic obstructive pulmonary disease, hypoxia, auditory pathway, audiometry, otoacoustic emissions spontaneous

ÖZ

Amaç: Bu çalışmada, kronik hipokseminin kronik obstrüktif akciğer hastalığı (KOAH) hastalarında işitsel işlevler üzerindeki etkisini incelemeyi amaçladık.

Gereç ve Yöntem: Çalışmaya solunum fonksiyon testi (SFT) yapılan ve KOAH tanısı alan 60 hasta dahil edildi. Çalışmada dört çalışma grubu ve bir kontrol grubu oluşturulmuştur. Her çalışma grubu zorlu ekspiratuvar hacim (FEV1) ve FEV1/zorlu vital kapasite (FVC) oranına göre belirlendi. Gruplar hafif, orta, şiddetli ve çok şiddetli KOAH hastalarından oluşuyordu. Her grup 15 hastayı içeriyordu. Kontrol grubu FEV1/FVC oranı >\%70 olan 30 hastadan oluşuyordu. Tüm hastalara saf ton odyometri ve otoakustik emisyon (OAE) testi uygulandı.

Bulgular: Odyolojik değerlendirmeye göre şiddetli ve çok şiddetli grup ile kontrol grubu arasında istatistiksel olarak anlamlı farklılık bulundu $(p<0,01)$.

Sonuç: Bu çalışmanın sonuçları, şiddetli ve çok şiddetli KOAH'ı hastalarda işitme mekanizmalarının da etkilenebileceğini göstermiştir. Bu çalışmanın yazarları, kronik hipokseminin işitme sistemi üzerindeki olumsuz etkilerini önlemek için KOAH hastalarında hastalığın erken evrelerinde gerekli önlemlerin alınması gerektiğini savunmaktadır.

Anahtar Kelimeler: Kronik obstrüktif akciğer hastalığı, hipoksi, işitsel yolak, odyometri, otoakustik emisyonlar spontan

Address for Correspondence: Tolga ERSÖZLÜ MD, Tekirdağ Namık Kemal University Faculty of Medicine, Department of Otorhinolaryngology, Head and Neck Surgery, Tekirdağ, Turkey

Phone: +90 5335711653 E-mail: tersozlu@nku.edu.tr ORCID ID: orcid.org/0000-0001-8629-6022

Received: 15.02.2021 Accepted: 31.03.2021

๑Copyright 2021 by the Tekirdağ Namık Kemal University Faculty of Medicine / Namık Kemal Medical Journal published by Galenos Publishing House. 


\section{INTRODUCTION}

Hypoxemia is a decrease in the partial pressure of oxygen (p02) in the blood. It is observed in almost all known pulmonary diseases. p02 is used to demonstrate pulmonary functions. On the other hand, hypoxia is a decrease in tissue oxygenation and results from hypoxemia. This hypoxic state, which occurs in tissues, triggers various events over time, causing destruction in cells'.

Hypoxemia is known to have a significant negative effect on the central and peripheral nervous system by disrupting the hemodynamic and biochemical regulatory mechanisms. As a result of chronically low oxygen saturation in the blood, a variety of pathologies, such as a decrease in adenosine levels and disruptions in the neurotransmitter cycle of neurons, are observed in the central nervous system ${ }^{2-4}$. In addition, it has been suggested that endothelial dysfunction occurs in the microcirculation due to recurrent oxidative stress secondary to chronic hypoxemia, and it disrupts the blood supply to peripheral nerves, causing inevitable damage to neuronal function ${ }^{5,6}$.

The auditory system consists of two mechanisms, the peripheral and central hearing, and is extremely sensitive to the effects of hypoxemia. For a normal auditory function, the transmission from the cochlea to the auditory cortex must be complete, and sufficient and continuous oxygen support must be provided to this nervous system?

Chronic obstructive pulmonary disease (COPD) is a disease that causes a decrease in expiratory flow rates. Moreover, patients have irregular ventilation that causes arterial hypoxemia and hypercapnia. As a result of this chronic hypoxemia, oxygen deprivation occurs in tissues and various comorbidities may develop. These abnormalities can be detected by pulmonary function tests (PFT) and arterial blood gases ${ }^{8}$.

Therefore, the present study was conducted considering that chronic hypoxemia observed in COPD patients might be harmful to the transduction and conduction mechanisms in the auditory pathways. This study aimed to examine the effect of chronic hypoxemia on auditory functions in COPD patients and to discuss the results within the context of the current literature.

\section{MATERIALS AND METHODS}

The study was conducted in a tertiary research hospital by obtaining the approval Tekirdağ Namık Kemal University of the Local Ethics Committee (2015/118/11/01) and all procedures were in accordance with the ethical standards of responsible committee on human experimentation (institutional and national) and with the 1975 Declaration of Helsinki, as revised in 2008. Additional informed consent was obtained from all patients whose data were included in this article. This study included patients with COPD who underwent a PFT with the pre-diagnosis of probable dyspnea between November 2015 and February 2016. PFT analyses were carried out in the PFT laboratory in the thoracic diseases department of the same faculty.

Comprehensive otorhinolaryngological examinations of all participants were performed (with 0 and 70-degree endoscopes). Those with conditions known to have a negative effect on the mechanism of hearing (patients with acute or chronic otorhinolaryngological disorders, otitis media, eustachian tube dysfunctions, Sino-nasal disorders, etc.), as well as chronic systemic diseases such as hypertension, diabetes mellitus, and chronic heart disease, which are known to be associated with microvascular circulation disorders, were not included in the study. Four study groups and a control group were created in the study.

Each study group was determined based on forced expiratory volume (FEV1) and FEV1/forced vital capacity (FVC) ratio. The first, second, third and fourth groups consisted of patients with Stage 1 (mild) FEV1/FVC $<70 \%$ and FEV1 $\geq 80 \%$, Stage 2 (moderate) FEV1/FVC 70\% and 50\% FEV1 80\%, Stage 3 (severe) FEV1/FVC $70 \%$ and 30\% FEV1 50\%, and Stage 4 (very severe) FEV1/FVC 70\% and FEV1 <30\% COPD, respectively (Table 1). Each group included 15 patients. The control group consisted of 30 patients with an FEV1/FVC ratio of $>70 \%$.

All patients underwent pure tone audiometry and otoacoustic emission (OAE) test. Pure tone audiometry was performed by the same audiologist using a two-channel audiometry (Interaccoustics, A/S, Denmark) in accordance with the international standards. Patients with a hearing threshold higher than $25 \mathrm{dBHL}$ were considered to have hearing loss. The severity of hearing loss was categorized as mild (26 to 40 $\mathrm{dBHL}$ ), moderate (41 to $55 \mathrm{dBHL}$ ), moderate-severe (56 to 70 $\mathrm{dBHL})$, severe (71 to $90 \mathrm{dBHL}$ ) and profound $(91+\mathrm{dBHL})$. The Madsen AccuScreen TE device (Otometrics, Denmark) was used for the OAE test.Normal outer hair cell function was determined

\begin{tabular}{|c|c|c|}
\hline $\begin{array}{l}\text { GOLD } \\
\text { stage }\end{array}$ & Severity & Spirometry \\
\hline 1 & Mild & FEV1/FVC $<0.7$ and FEV $1 \geq 80 \%$ predicted \\
\hline II & Moderate & $\begin{array}{l}\text { FEV } 1 / F V C<0.7 \text { and FEV } 1 \geq 50 \% \text { but }<80 \% \\
\text { predicted }\end{array}$ \\
\hline III & Severe & $\begin{array}{l}\text { FEV } 1 / F V C<0.7 \text { and FEV } 1 \geq 30 \% \text { but }<50 \% \\
\text { predicted }\end{array}$ \\
\hline IV & Very severe & FEV1/FVC $<0.7$ and FEV $1<30 \%$ \\
\hline
\end{tabular}


according to the "Passed/Clear response" result. Those with the result of "refer/unclear response" were retested. Those with a permanent "refer/unclear response" result was considered to have sensorineural hearing loss.

\section{Statistical Analysis}

Statistical data analysis was performed using Statistical Package for the Social Sciences (SPSS) for Windows, version 17 (SPSS Inc., Chicago, IL, USA). The chi-square $\left(\chi^{2}\right)$ test was used to compare qualitative data. The Kruskal-Wallis test was employed to compare the groups. Dunn's multiple comparison test and the Tukey's range test were used to compare the subgroups. Results were considered significant for $p<0.05$.

\section{RESULTS}

The ages of the 90 participants (60 COPD patients and 30 controls) ranged between 45 and 54 (mean age $=46.6$ ) years. Forty-six (51.1\%) females and 44 (48.9\%) males were included.

There was no statistically significant difference between the groups in terms of demographic characteristics ( $p=0.765$ ).

In addition, there was no statistically significant difference between male and female genders in terms of hearing loss and OAE results ( $p=0.976, p=0.464, p<0.05)$.

Based on FEV1 (\% expected) value according to the Global Initiative for COPD, the study groups consisted of patients with Stage 1 (mild) COPD FEV1/FVC $<70 \%$ and FEV1 $\geq 80 \%$, Stage 2 (moderate) COPD FEV1/FVC 70\% and 50\% FEV1 80\%, Stage 3 (severe) COPD FEV1/FVC 70\% and 30\% FEV1 50\%, and Stage 4 (very severe) COPD FEV1/FVC 70\% and FEV1 30\%. Each group consisted of 15 patients. The control group consisted of 30 patients with an FEV1/FVC ratio of $>70 \%$.

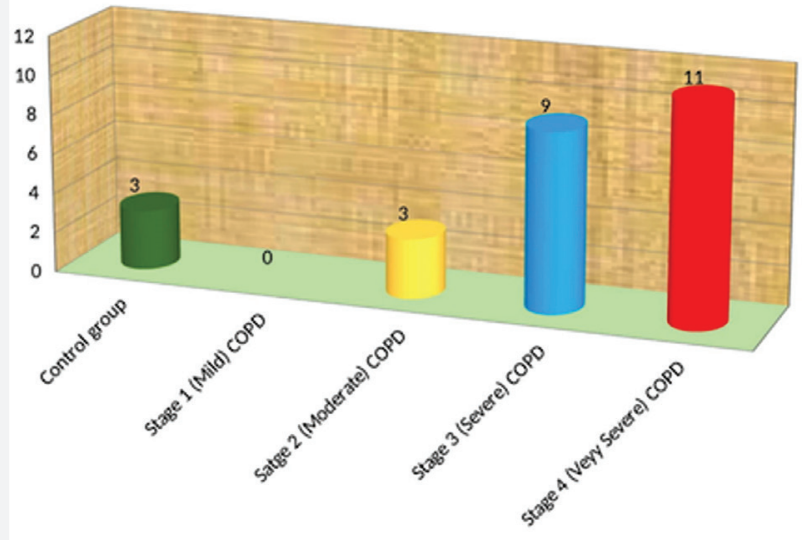

Figure 1. Number of patients with more than $25 \mathrm{~dB}$ sensorineural hearing loss in groups

COPD: Chronic obstructive pulmonary disease
The mean ages for the COPD groups including 15 patients with Stage 1 (mild), 15 patients with Stage 2 (moderate), 15 patients with Stage 3 (severe) and 15 patients with Stage 4 (very severe) COPD and the control group including 30 patients were $45.86 \pm 8.6,46.20 \pm 8.7,44.60 \pm 8.1,45.13 \pm 7.6$, and $45.56 \pm 7.7$, respectively.

Three of the 30 patients in the control group, none of the 15 patients with Stage 1 (mild) COPD, 3 of the 15 patients with Stage 2 (moderate) COPD, 9 of the 15 patients with Stage 3 (severe) COPD, and 11 of the 15 patients with Stage 4 (very severe) COPD had sensorineural hearing loss (the hearing levels were greater than $25 \mathrm{~dB}$ ) (Figure 1).

The mean hearing thresholds for the control group and mild, moderate, severe and very severe COPD groups were15.73 \pm 6.0

\section{Hearing thresholds}

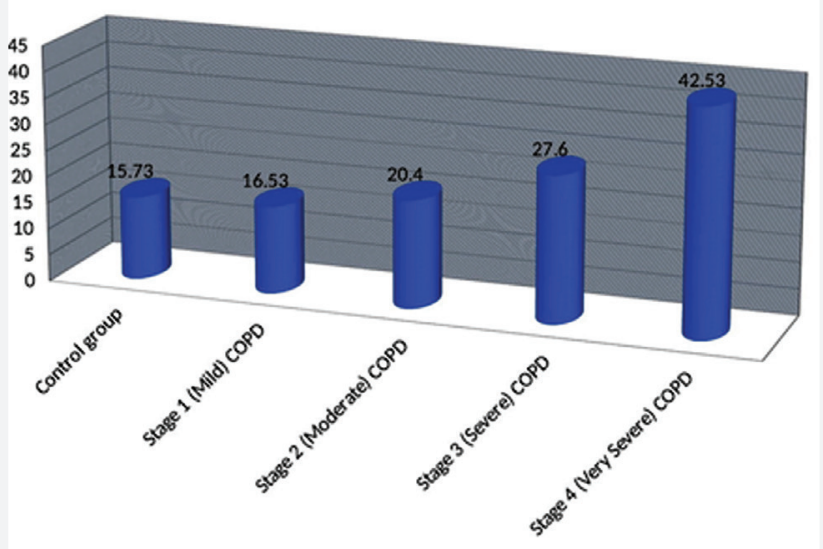

Figure 2. Hearing values in groups COPD: Chronic obstructive pulmonary disease

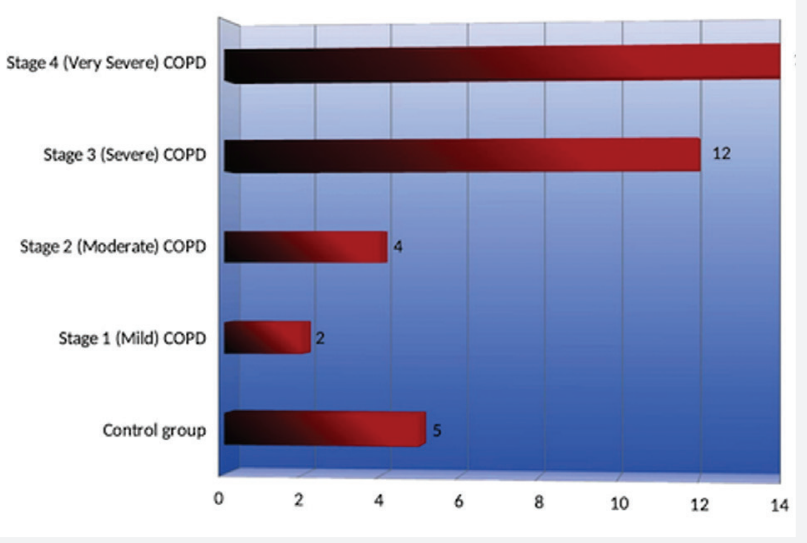

Figure 3. Number of patients who failed the auto acoustic emission test in groups

COPD: Chronic obstructive pulmonary disease 
$\mathrm{dBHL}, 16.53 \pm 5.2 \mathrm{dBHL}, 20.4 \pm 8.9 \mathrm{dBHL}, 27.6 \pm 9.7 \mathrm{dBHL}$, and $42.53 \pm 17.4 \mathrm{dBHL}$, respectively (Figure 2 ). According to the audiological evaluation, the results of the patients in the control group and the patients in the mild and moderate COPD groups were below the expected values, while the results of the patients in the severe and very severe COPD groups were higher than expected. There was a statistically significant difference compared to the control group $(p<0.001)$.

In the OAE test results, 5 of the 30 patients in the control group failed in the OAE test, while 2 of the 15 patients with Stage 1 (mild) COPD, 4 of the 15 patients with Stage 2 (moderate) COPD, 12 of the 15 patients with Stage 3 (severe) COPD and 14 of the 15 patients with Stage 4 (very severe) COPD failed in the OAE test (Figure 3).

According to the OAE results of the patients, the results of the patients in the control group and the patients in the mild and moderate COPD groups were below the expected values, while the results of the patients in the severe and very severe COPD groups were higher than expected. There was a statistically significant difference compared to the control group $(p<0.001)$.

\section{DISCUSSION}

COPD is a multisystemic disease with comorbidities ${ }^{9}$. COPD has significant effects on cognitive functions and verbal memory, especially on the central nervous system ${ }^{10}$.

The findings and comorbidities of COPD are the results of systemic "spread" caused by inflammation in the lungs triggered by the chronic hypoxic state of COPD patients and occur by resulting in multiple organ dysfunction ${ }^{11}$.

COPD-induced hypoxemia falls into one of two hypoxemic states described in the literature. The first one is characterized by short-interval and recurrent attacks of hypoxemia, as observed in obstructive sleep apnea syndrome patients. The second hypoxemic state is a chronic persistent hypoxemic state, as observed in those living at higher altitudes or patients with COPD. This chronic decrease in oxygen saturation causes oxygen deprivation in tissues over time, resulting in hypoxia and initiating end-organ damage. Thus, it triggers the systemic effects of COPD. There is evidence of systemic inflammation measured by an increase in circulating cytokines, chemokines and acute phase proteins or abnormalities of circulating cells in COPD patients, especially when the disease is severe and during exacerbations $^{12}$. Both systemic inflammation and chronic hypoxia create mechanisms that trigger each other, causing a decrease in blood supply to the peripheral nerve and preventing oxygen supply.

The results of the study conducted in the light of these data indicate that Stage 3 (severe) and Stage 4 (very severe) COPD can result in sensorineural hearing loss. This result is consistent with the previous studies in the literature reporting that COPDinduced hypoxemia may have a negative effect on auditory function ${ }^{13,14}$.

In the literature review performed to evaluate the relationship between COPD and the affection of the auditory system, there were studies showing that the arterial transport mechanism in the inner ear was closely associated with the cochlear oxygen reserve and that the decrease in oxygen level greatly affected the inner ear cells ${ }^{15}$. In addition, most studies have shown that reductions in oxygen supply to the cochlea directly affect the functions of the cochlea ${ }^{16,17}$. In addition, decreases have been observed in distortion product OAEs (DPOAEs) and endocochlear potential values based on hypoxia ${ }^{18,19}$.

Various studies have found changes in auditory brainstem responses and cortical auditory evoked potentials of experimental animals exposed to hypoxia ${ }^{20}$. The results of the present study showed that patients with Stage 1 (mild) and Stage 2 (moderate) COPD did not have impaired auditory functions, while patients with both Stage 3 (severe) and Stage 4 (very severe) COPD had sensorineural hearing loss. Although our study yielded such a result, there is a need for further studies with greater participation to define the link between FEV1 value and severity of hearing loss in COPD patients.

\section{Study Limitations}

The presence of additional risk factors (smoking, diabetes type 2 , old age) that negatively affect the auditory pathway in terms of hypoxia in COPD patients can be considered as a limitation of the study. When we use these additional risk factors as exclusion criteria, we would like to state that, as mentioned in the literature, we had to continue working with a population that was 20\% of the COPD patient group who did not smoke ${ }^{21}$.

\section{CONCLUSION}

In conclusion, there is convincing evidence that the risk of advanced dysfunction in the vascular and nervous structures of the body is inevitable for patients suffering from chronic hypoxemia secondary to COPD. The results of the present study have showed that auditory mechanisms may also be affected in patients with severe and very severe COPD. The authors of this study argue that necessary measures should be taken in the early stages of the disease for COPD patients to prevent the negative effects of chronic hypoxemia on the auditory system.

\section{Ethics}

Ethics Committee Approval: The study were approved by the Tekirdağ Namık Kemal University of Local Ethics Committee (protocol number: 2015/118/11/01, date: 10/12/2015). 
Informed Consent: Additional informed consent was obtained from all patients whose data were included in this article.

Peer-review: Externally peer-reviewed.

\section{Authorship Contributions}

Concept: M.D., Design: T.E., Data Collection or Processing: O.B.D., Analysis or Interpretation: T.E., Literature Search: T.E., M.D., Writing: O.B.D., T.E.

Conflict of Interest: No conflict of interest was declared by the authors.

Financial Disclosure: The authors declared that this study received no financial support.

\section{References}

1. Barberà JA, Roca J, Ferrer A, Félez MA, Díaz O, Roger N, et al. Mechanisms of worsening gas exchange during acute exacerbations of chronic obstructive pulmonary disease. Eur Respir J. 1997;10:1285-91.

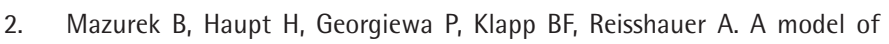
peripherally developing hearing loss and tinnitus based on the role of hypoxia and ischemia. Med Hypotheses. 2006;67:892-9.

3. Carlile S, Bascom DA, Paterson DJ. The effect of acute hypoxia on the latency of the human auditory brainstem evoked response. Acta Otolaryngol. 1992;112:939-45.

4. Johnston MV. Neurotransmitter alterations in a model of perinatal hypoxic-ischemic brain injury. Ann Neurol. 1983;13:511-8.

5. Atkeson A, Jelic S. Mechanisms of endothelial dysfunction in obstructive sleep apnea. Vasc Health Risk Manag. 2008;4:1327-35.

6. Schwarz El, Puhan MA, Schlatzer C, Stradling JR, Kohler M. Effect of CPAP therapy on endothelial function in obstructive sleep apnoea: A systematic review and meta-analysis. Respirology. 2015;20:889-95.

7. Papandreou C. Levels of TBARS are inversely associated with lowest oxygen saturation in obese patients with OSAS. Sleep Breath. 2013;17:1319-22.

8. Niewoehner DE, Sobonya RE. Structure-function correlations in chronic airflow obstruction. Baum GL, Wolinsky E, (Eds). Textbook of Pulmonary Diseases, Little, Brown and Company, Boston. 1989;p.913.
9. Baty F, Putora PM, Isenring B, Blum T, Brutsche M. Comorbidities and burden of COPD: a population based case-control study. PLoS One. 2013;8:e63285

10. Incalzi RA, Gemma A, Marra C, Capparella O, Fuso L, Carbonin P. Verbal memory impairment in COPD: its mechanisms and clinical relevance. Chest. 1997;112:1506-13.

11. Sevenoaks MJ, Stockley RA. Chronic Obstructive Pulmonary Disease, inflammation and co-morbidity--a common inflammatory phenotype? Respir Res. 2006;7:70.

12. Wouters EF, Groenewegen KH, Dentener MA, Vernooy JH. Systemic inflammation in chronic obstructive pulmonary disease: the role of exacerbations. Proc Am Thorac Soc. 2007;4:626-34.

13. El-Kady MA, Durrant JD, Tawfik S, Abdel-Ghany S, Moussa AM. Study of auditory function in patients with chronic obstructive pulmonary diseases. Hear Res. 2006;212:109-16.

14. Atiş $\mathrm{S}$, Ozge A, Sevim S. The brainstem auditory evoked potential abnormalities in severe chronic obstructive pulmonary disease. Respirology. 2001;6:225-9.

15. Gafni M, Sohmer H. Intermediate endocochlear potential levels induced by hypoxia. Acta Otolaryngol. 1976;82:354-8.

16. Perlman HB, Kımura R, Fernandez C. Experiments on temporary obstruction of the internal auditory artery. Laryngoscope. 1959;69:591-613.

17. Prazma J, Fischer ND, Biggers WP, Ascher D. A correlation of the effects of normoxia, hyperoxia and anoxia on P02 of endolymph and cochlear potentials. Hear Res. 1978;1:3-9.

18. Rebillard G, Lavigne-Rebillard M. Effect of reversible hypoxia on the compared time courses of endocochlear potential and 2f1-f2 distortion products. Hear Res. 1992;62:142-8.

19. Rebillard G, Klis JF, Lavigne-Rebillard M, Devaux P, Puel JL, Pujol R. Changes in 2f1-f2 distortion product otoacoustic emissions following alterations of cochlear metabolism. Br J Audiol. 1993;27:117-21.

20. Lucertini M, Ciniglio Appiani G, Antonini R, Urbani L. Effects of hypobaric hypoxia on the middle-latency and steady-state auditory evoked potentials. Audiology. 1993;32:356-62.

21. Lamprecht B, McBurnie MA, Vollmer WM, Gudmundsson G, Welte $T$ Nizankowska-Mogilnicka $E_{\text {, et }}$ al. COPD in never smokers: results from the population-based burden of obstructive lung disease study. Chest. 2011;139:752-63. 